\section{Proteolytic profile of Treponema vincentii ATCC 35580 with special reference to collagenolytic and arginine aminopeptidase activity}

\author{
Mäkinen KK, Syed SA, Loesche WJ, Mäkinen P-L. Proteolytic profile of Trepone- \\ ma vincentii $A T C C 35580$ with special reference to collagenolytic and arginine \\ aminopeptidase activity. \\ Oral Microbiol Immunol: 1988: 3: 121-128.
}

The proteolytic profile of Treponema vincentii ATCC 35580 was studied using PZPLGPA (phenylazobenzyloxycarbonyl-L-prolyl-L-leucylglycyl-L-prolyl-D-arginine; a substrate of bacterial collagenases) and amino acid 2-naphthylamides (2NA) as substrates. The cell extracts showed high activity toward PZ-PLGPA, $\mathrm{Na}$-Larginyl-2NA and $N \gamma$-L-glutamyl-2NA. Gel permeation chromatography revealed 2 major endopeptidases (I and II) hydrolyzing PZ-PLGPA, the molecular weights of which were 75,000 and 23,000, respectively. Enzyme I was stable enough for subsequent fast protein liquid chromatography on an anion exchange column. The enzyme had a broad $\mathrm{pH}$ optimum of 6.5 to 7.5 with PZ-PLGPA as substrate, hydrolyzed gelatin and was moderately inhibited by metal chelators, but was very sensitive to $p$-chloromercuribenzoic acid (PCMB). Enzyme II with a $\mathrm{pH}$ optimum of 7 to 8 was more labile, quite sensitive to PCMB and moderately inhibited by chelators. A high-molecular weight arginine aminopeptidase (mol. wt. $>200,000)$ was sensitive to PCMB and showed a value of $0.55 \mathrm{mM}$ for $K_{m}$ in the hydrolysis of $N a$-L-arginyl-2NA. The hydrolysis of PZ-PLGPA and gelatin suggests that this organism may contain collagenolytic proteinases. Because the insoluble proteinase substrate Azocoll was not hydrolyzed, these enzymes may be active on soluble collagenous substances only. T. vincentii ATCC 35580 typifies an organism rich in PZ-PLGPA-endopeptidase, arginine aminopeptidase and $\gamma$-glutamylpeptidase activity.
Kauko K. Mäkinen, Salam A. Syed, Walter J. Loesche, Pirkko-Liisa Mäkinen

School of Dentistry, The University of Michigan, Ann Arbor, U.S.A.

Key words: spirochetes; proteolytic enzymes periodontal disease

Dr. Kauko K. Mäkinen, Department of Biologic and Materials Sciences, The University of Michigan, Ann Arbor, MI 48109-1078, U.S.A.

Accepted for publication April 30, 1988
Spirochetes are helically shaped, heterotrophic bacteria which are particularly prominent in the subgingival plaque when there is evidence of clinical disease, such as gingival bleeding, periodontal inflammation and suppuration (16). The chemical aggressiveness of oral spicochetes may partly be associated with the presence of proteoytic enzymes which are active toward host tissue proteins, such as collagen and other connective tissue components. The physiology, morphology and evolution of spirochetes have been actively studied $(8,13)$, but the chemistry of proteolytic enzymes produced by spirochetes has received attention only recently $(11$, 20, 21, 28, 40, 43).

Many of the oral spirochetes are not readily mass-cultured because they are nutritionally fastidious (39). The culti- vable spirochetes are, therefore, generally grown in complex media supplemented with serum or other biological fluids. Such strict nutritional requirements of many spirochetes should be reflected in the number and types of proteolytic enzymes formed by these organisms. Previous studies have indeed demonstrated several proteolytic enzymes produced by Treponema denticola, a host-associated spirochete present in the human periodontal pocket (11, 20, 21, 28, 43). The enzymes demonstrated in $T$. denticola represent endopeptidases, iminopeptidases, aminopeptidases, collagenolytic proteinases and peptidases showing so called BANA-activity (connoting that the enzymes hydrolyze $N$-benzoyl-DL-arginine-2-napthylamide) $(20,28)$. Only one proteolytic enzyme from a human oral spirochete (the BANA-hydrolyzing peptidase of $T$. denticola strain ASLM) has been subjected to chemical studies (Mäkinen KK, Chen C-Y, et al. 1988). Chemical modification of the benzoylarginine peptidase from $T$. denticola (strain ASLM), a human oral spirochete: evidence for active site carboxyl groups. Submitted). Virtually nothing is known about the proteolytic enzymes produced by another human oral spirochete, Treponema vincentii ATCC 35580. The purpose of this study was to characterize this organism with regard to its overall proteolytic activity and to report results on collagenolytic endopeptidases and arginine aminopeptidases present in this spirochete. The collagenolytic activity of $T$. vincentii ATCC 35580 was studied using as substrate a chromogenic pentapeptide derivative, i.e. phenyl- 
azobenzyloxycarbonyl-L-prolyl-Lleucylglycyl-L-prolyl-D-arginine (PZPLGPA) which is typically hydrolyzed at the Leu-Gly bond by "true" collagenases $(3,22,46)$ and several other collagenolytic enzymes. In fact, microbial extracellular proteinases specifically hydrolyzing PZ-PLGPA or similar synthetic substrates at the Leu-Gly bond, have been regarded as "collagenolytic enzymes" $(3,22,46)$. The presence of such activity in $T$. vincentii suggests that the pathogenicity of this organism in periodontal disease may partly depend on the activity of those enzymes.

\section{Material and methods \\ Source of the organism and treatment of the cells}

The cells of $T$. vincentii ATCC 35580 were maintained with bi-weekly transfers in Tryptone-heart infusion-yeast extract broth (39). The cells were grown anaerobically normally in 100-500 ml broth for $72 \mathrm{~h}$. The cells were harvested by centrifugation for $10 \mathrm{~min}$ at 16,500 $\mathrm{g}$, washed 3 times with $10 \mathrm{mM}$ Tris- $\mathrm{HCl}$, pH 7.0 (containing $0.1 \mathrm{mM} \mathrm{CaCl}_{2}$ ), and finally resuspended in $10 \mathrm{ml}$ of buffer. The suspensions were treated for $2 \mathrm{~min}$ with a Branson Sonifier model W1850D (Branson Sonic Power Company, Plainview, NY) in an iced water bath. The sonicates were centrifuged for $10 \mathrm{~min}$ at $12,000 \mathrm{~g}$ and the supernatant fluids were tested with various proteolytic enzyme substrates as indicated below (in the experiment shown in Fig. 1, centrifugation took place at $4,500 \mathrm{~g}$ ). The sonicates were stored at $-20^{\circ} \mathrm{C}$ and required recentrifugation after thawing for further studies. $T$. denticola ATCC 35405 was cultivated and the cells were treated as above.

\section{Enzyme and protein assays}

Aminopeptidase activity with 2-naphthylamine (2NA) derivatives of amino acids was determined using an azocoupling metod (19). Benzoylarginine peptidase activity was studied with $N$ $a$-benzoyl-DL-arginine- $p$-nitroanilide (BAPNA) $(10,18)$. Endopeptidase activity (collagenolytic) was tested using PZ-PLGPA as substrate as described by Wünsch and Heidrich (46). Azocoll (9, 24), Azocasein (33) and elastin-orcein (30) were tested as substrates according to the specific methods given. In kinetic studies initial velocities were measured,

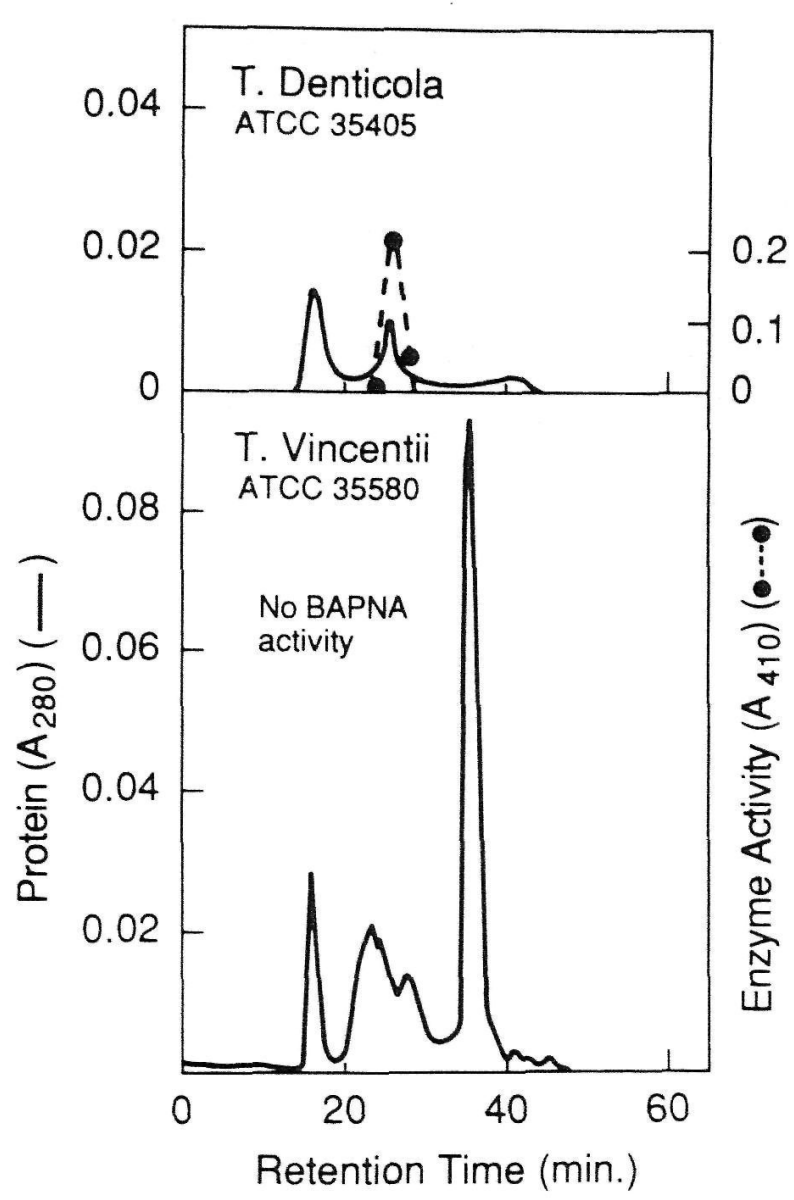

Fig. 1. FPLC on a Superose 12 gel column of the proteins present in the centrifuged (10 $\min 4,500 \mathrm{~g})$ and ACRO-filtered $(0.2 \mu)$ sonicates of $T$. denticola ATCC 35405 and $T$. vincentii ATCC 35580 . The chromatographic fractions were tested for enzymes hydrolyzing BAPNA. The column was equilibrated and eluted with $0.1 \mathrm{M}$ Tris- $\mathrm{HCl}, \mathrm{pH} 7.5$ (containing $50 \mathrm{mM} \mathrm{NaCl}$ ) at a flow rate of $0.5 \mathrm{ml} /$ min.

whereas in FPLC and Sephadex G-200 chromatography the reaction times were sometimes prolonged (up to $17 \mathrm{~h}$ ) for the detection of minor enzyme peaks (which were undetectable in short incubation). Protein was determined according to Bradford (6) using Sigma bovine serum albumin as a standard protein, or by using the "absolute" method of Whitaker and Granum (45).

\section{Chemicals and other materials}

Unless otherwise indicated, the chemicals were obtained from Sigma Chemical Co. (St. Louis, MO). The water used in this study was prepared with a Millipore-Milli-Q system and had a resistivity of $18 \mathrm{M} \Omega \mathrm{cm}^{-1}$. All samples intended for FPLC were filtered immediately before injection through ACRO LC13 $0.2 \mu$ filters (Gelman Sciences, Ann Arbor, MI). Concentration of enzymes was performed with Centricon-10 or Centricon-30 membranes (Amicon, Lexington, MA).

\section{Determination of $K_{\mathrm{m}}$ values}

The $K_{m}$ values were determined by plotting the velocity data using the Linewea-
ver-Burk's, Hanes' and Hofstee's methods with special consideration of substrate inhibition (32).

\section{Amino acid analysis}

The nature of the peptide bond (LeuGly) hydrolyzed in PZ-PLGPA by the $T$. vincentii enzymes was checked by studying the amino acid conposition of the hydrolysis products. For this purpose a Beckman Model 6300 Automated Amino Acid Analyzer was used. The hydrolysis products of PZ-PLGPA, separated by reversed-phase chromatography on a PepRPC HR5/5 column, were treated for $4 \mathrm{~h}$ at $+145^{\circ} \mathrm{C}$ before analysis. Norleucine was used as an internal standard.

\section{Results \\ Peptidolytic activity of the sonicates}

The supernatant fraction derived from ultrasonic preparations of washed cells of $T$. vincentii displayed considerable activity toward PZ-PLGPA and Azocasein, but hydrolyzed BANA at a very low rate (Tables 1,2). Table 2 shows that out of the 24 amino acid-2NAs tested only N-L-arginine-2NA (arg-2NA) and $\gamma$-L-glutamyl-2NA were hydrolyzed at a high rate. Based on these specificity studies, the fractions in subsequent chromatographic separations were tested for collagenolytic and arginine aminopeptidase activity using PZPLGPA and arg-2NA as substrates. The hydrolysis of PZ-PLGPA observed in this study occurred at the Leu-Gly bond only. This was proven by subjecting the reaction mixtures to reversed phase

Table 1. Activity of the cell sonicate of $T$. vincentii (strain ATCC 35580) toward some peptidase substrates*

\begin{tabular}{ll}
\hline Substrate & Specific activity \\
\hline PZ-PLGPA & $\begin{array}{l}1.53 \mu \mathrm{mol} \mathrm{min}^{-1} \cdot \mathrm{mg}^{-1} \\
\left(\times 10^{-3}\right)\end{array}$ \\
Azocasein & $5.1 \times 10^{-3} \quad$ enzyme units \\
& $\mathrm{min}^{-1} \cdot \mathrm{mg}^{-1 * *}$ \\
BAPNA & $1.5 \quad \mu \mathrm{mol} \cdot \mathrm{min}^{-1} \cdot \mathrm{mg}^{-1}$ \\
& $\left(\times 10^{-5}\right)$ \\
Azocoll & $\mathrm{Nil}$ \\
Elastin-orcein & $\mathrm{Nil}$
\end{tabular}

* The reactions were performed in $50 \mathrm{mM}$ Tris- $\mathrm{HCl}$ buffer $(\mathrm{pH} 7.0)$ at $30^{\circ} \mathrm{C}$ using methods indicated in the Material and methods section, and the supernatant obtained after centrifugation of the cell sonicate for $10 \mathrm{~min}$ at $12,000 \mathrm{~g}$.

** In collagenase units as defined in Calbiochem-Boehring Doc. No. 3805-880. 
FPLC (only PZ-Pro-Leu and Gly-ProArg were detected) and determining the amino acid composition of the products of enzymatic breakdown of PZPLGPA.

In contrast to the sonicates obtained from $T$. denticola $(20,21)$ the $T$. vincentii sonicates were more difficult to treat on Amicon and Gelman membranes because of the presence of large amounts of high-molecular weight proteinaceous substances. This is shown in Fig. 1 which compares the protein chromatograms of T. vincentii ATCC 35580 and T. denticola ATCC 35405. T. vincentii always produced a more complex protein pattern and higher absorption of fractions at $280 \mathrm{~nm}$. The nature of these proteinaceous substances remains to be studied. These chromatograms were obtained with small $(25 \mathrm{ml})$ volumes of cells and by using several membrane filters to clarify the sonicates.

As expected $(20,21,28)$, FPLC separation on a Superose 12 column showed T. denticola to contain enzymes hydrolyzing BAPNA at a high rate, whereas $T$. vincentii did not produce measurable BAPNA-hydrolyzing activity; the low activity indicated in Table 1 was, thus, not sufficient for chromatography.

\section{Preparative gel chromatography}

Separation of $T$. vincentii collagenolytic enzymes and arginine aminopeptidases from 100 - to $500-\mathrm{ml}$ cultures on a Sephadex G-200 gel column is shown in Fig. 2. Because of the presence of large amounts of substances clogging the filters normally used before FPLC, the supernatant fluids of the sonicates were chromatographed on a larger Sephadex G-200 column. Two major collagenolytic enzymes with a molecule weight of about 75,000 and 23,000 , respectively, were revealed. Both displayed some heterogeneity which in repeated separations was found to result mostly from experimental conditions (normal variations in long-term incubation) rather than from true enzyme microheterogeneity. The arginine aminopeptidase activity appeared as several distinctly different peaks, most of which were considered to represent true enzyme heterogeneity.

The chromatographic pattern shown in Fig. 2 was found to be reproducible for the collagenolytic enzyme II, whereas the relative size of collagenolytic enzyme peak I and the fractionation pattern of the arginine aminopeptidases

Table 2. Activity of the cell sonicate of T. vincentii (strain ATCC 35580) and the high-molecular weight arginine aminopeptidase preparation on various amino acid $2 \mathrm{NAs}$ in $50 \mathrm{mM}$ Tris- $\mathrm{HCl}$ buffer $\left(\mathrm{pH} 7.0 ; 30^{\circ}\right)$. The sonicated sample was centrifuged for $10 \mathrm{~min}$ at $10,000 \mathrm{~g}$ before use. This enzyme was obtained by concentrating the void volume fractions of a Sephadex G-200 separation (similar to Fig. 2). BANA $=N a$-benzoyl-DL-arginyl-2NA.

\begin{tabular}{lcc}
\hline Substrate & $\begin{array}{c}\text { Cell sonicate } \\
\left(\mu \mathrm{mol} \cdot \mathrm{min}^{-1} \cdot \mathrm{mg}^{-1} \times 10^{-5}\right)\end{array}$ & $\begin{array}{c}\text { Arginine aminopeptidase } \\
(\text { Relative activity; arg-2NA }=100)\end{array}$ \\
\hline Aspartyl-2NA & 1.2 & 12 \\
Alanyl-2NA & 7.8 & 29 \\
Arginyl-2NA & 158.3 & 100 \\
BANA & 0.8 & 14 \\
$a$-Glutamyl-2NA & 7.8 & 58 \\
-Glutamyl-2NA & 49.1 & $280^{*}$ \\
Histidyl-2NA & 14.0 & 12 \\
Isoleucyl-2NA & 2.0 & 0 \\
Leucyl-2NA & 8.0 & 17 \\
Lysyl-2NA & 14.7 & 31 \\
Methionyl-2NA & 2.1 & 13 \\
Prolyl-2NA & 2.9 & 0 \\
Pyrrolidonyl-2NA & 3.5 & 0 \\
Threonyl-2NA & 4.0 & 5 \\
Tryptophyl-2NA & 3.0 & 3 \\
Tyrosyl-2NA & 3.2 & 3 \\
Valyl-2NA & 1.6 & 8 \\
Hydroxyprolyl-2NA & 1.0 & 5 \\
Cysteinyl-2NA & 2.5 & 2 \\
Glycyl-2NA & 1.2 & 4 \\
Seryl-2NA & 1.5 & 8 \\
Glycylprolylleucyl-2NA & 1.4 & 0 \\
Glycylglycyl-2NA & 3.6 & 5 \\
Leucylglycyl-2NA & 1.5 & 13 \\
\hline
\end{tabular}

* Reflects most likely the presence of a $\gamma$-glutamyl peptidase. showed greater variability. Depending on conditions that remain to be elucidated more thoroughly, other similar cultivations resulted in a much higher void volume arginine aminopeptidase peak than that shown in Fig. 2. Since the activity of the low-molecular weight arginine aminopeptidases was rapidly lost and since the high-molecular weight enzyme turned out to be more stable, the latter was partly characterized. The active fractions of the 2 collagenolytic enzymes and the major arginine aminopeptidase peaks were pooled, the pools were concentrated on Amicon membranes, and the resulting PZ-PLGPAhydrolyzing enzymes subjected to FPLC as shown below.

\section{FPLC on a Mono $Q$ column}

The concentrates from the previous step were injected into a Mono Q anion exchange column. Applying a three-phase $\mathrm{NaCl}$ gradient indicated in Fig. 3, a successful separation of collagenolytic enzyme I was achieved. However, this procedure was destructive to collagenolytic enzyme II. Pretreatment of this enzyme with sulphydryl compounds, metal chelators or metal cations, or the presence of these substances in elution buffers, did not significantly improve the result. Collagenolytic enzyme I was eluted out of the column at the highest $\mathrm{NaCl}$ concentration employed, indicating tight binding to the gel. This enzyme did not contain detectable amounts of other proteolytic enzymes (tested on substrates mentioned in Tables 1,2) and it was considered suitable for various characterization studies. Table 3 shows the specific activity of the enzyme at various stages of the partial purification. Enzyme II showed the highest specific activity before FPLC suggesting that this enzyme may be the dominant collagenolytic proteinase of $T$. vincentii ATCC 35580 . However, its lability did not allow further purification and hence this enzyme was characterized following simple Sephadex G-200 chromatography. This enzyme was devoid of other significant proteolytic activity, i.e. out of the substrates shown in Tables 1 and 2 , it hydrolyzed only PZ-PLGPA at a high rate.

\section{Properties of collagenolytic enzyme I}

The effect of $\mathrm{pH}$ on the hydrolysis of PZ-PLGPA by enzyme I is shown in Fig. 4A. The highest rate of hydrolysis 


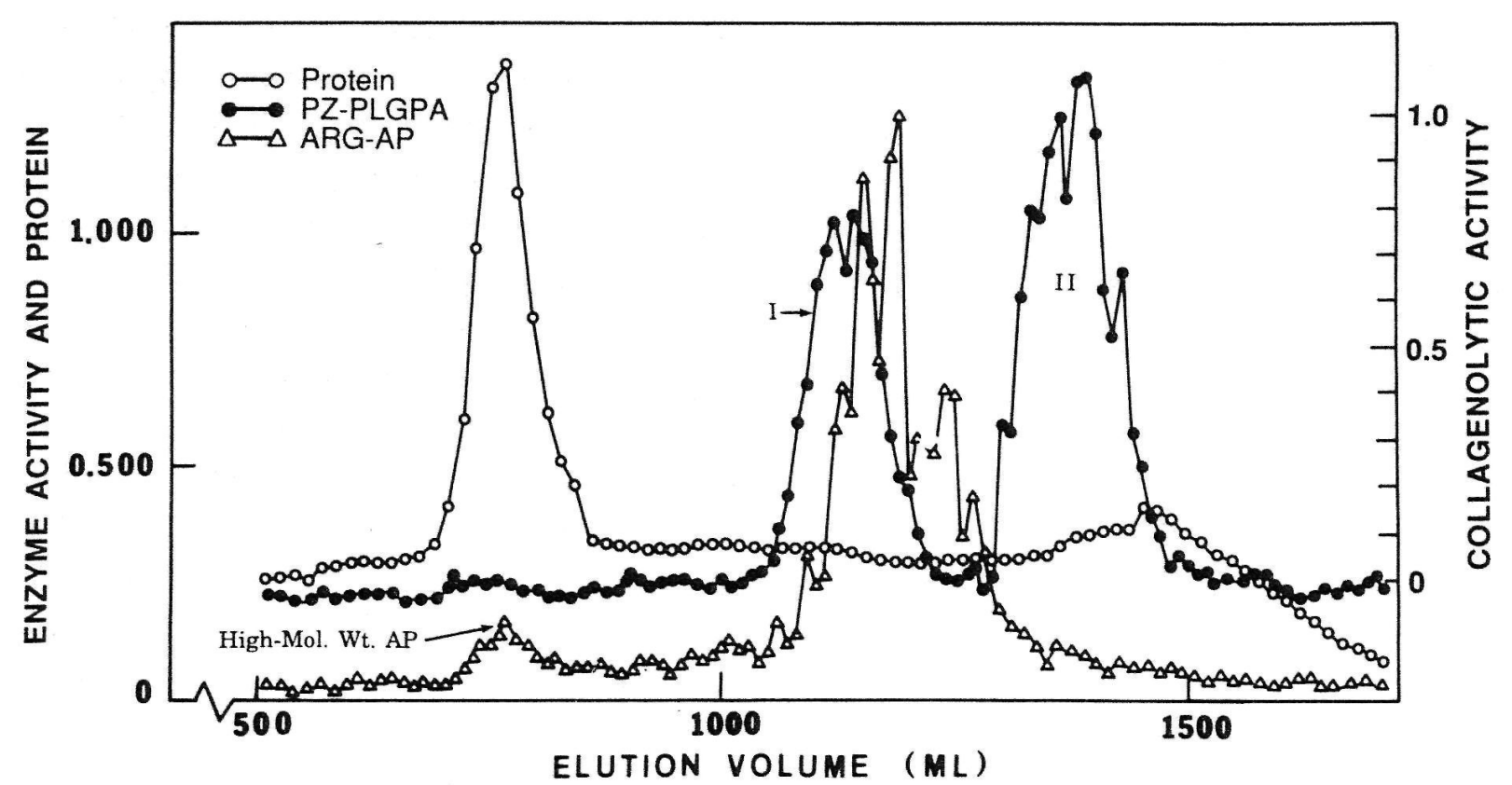

Fig. 2. Separation of collagenolytic enzymes and arginine aminopeptidase-like enzymes of the cell sonicate (centrifuged for $10 \mathrm{~min}$ at $12,000 \mathrm{~g}$ ) of $T$. vincentii ATCC 35580 on a Sephadex $\mathrm{G}-200$ column $(5 \mathrm{~cm} \times 88 \mathrm{~cm})$. The column was equilibrated and eluted with $50 \mathrm{mM}$ Tris- $\mathrm{HCl}$ buffer ( $\mathrm{pH} 7.8$, containing $1.0 \mathrm{mM} \mathrm{CaCl}_{2}$ ) at a flow rate of $0.5 \mathrm{ml} / \mathrm{min} .40 \mathrm{ml}$ of the centrifuged sonicate was applied on the column. The active fractions were pooled and dialyzed. I and II stand for the major collagenolytic enzymes revealed. The elution of the high-molecular weight arginine aminopeptidase (AP) is indicated. Collagenolytic activity is in $\mathrm{A}_{320}$ (PZ-PLGPA as substrate), protein in $\mathrm{A}_{280}$ and arginine aminopeptidase activity ("enzyme activity") in $\mathrm{A}_{525}$.

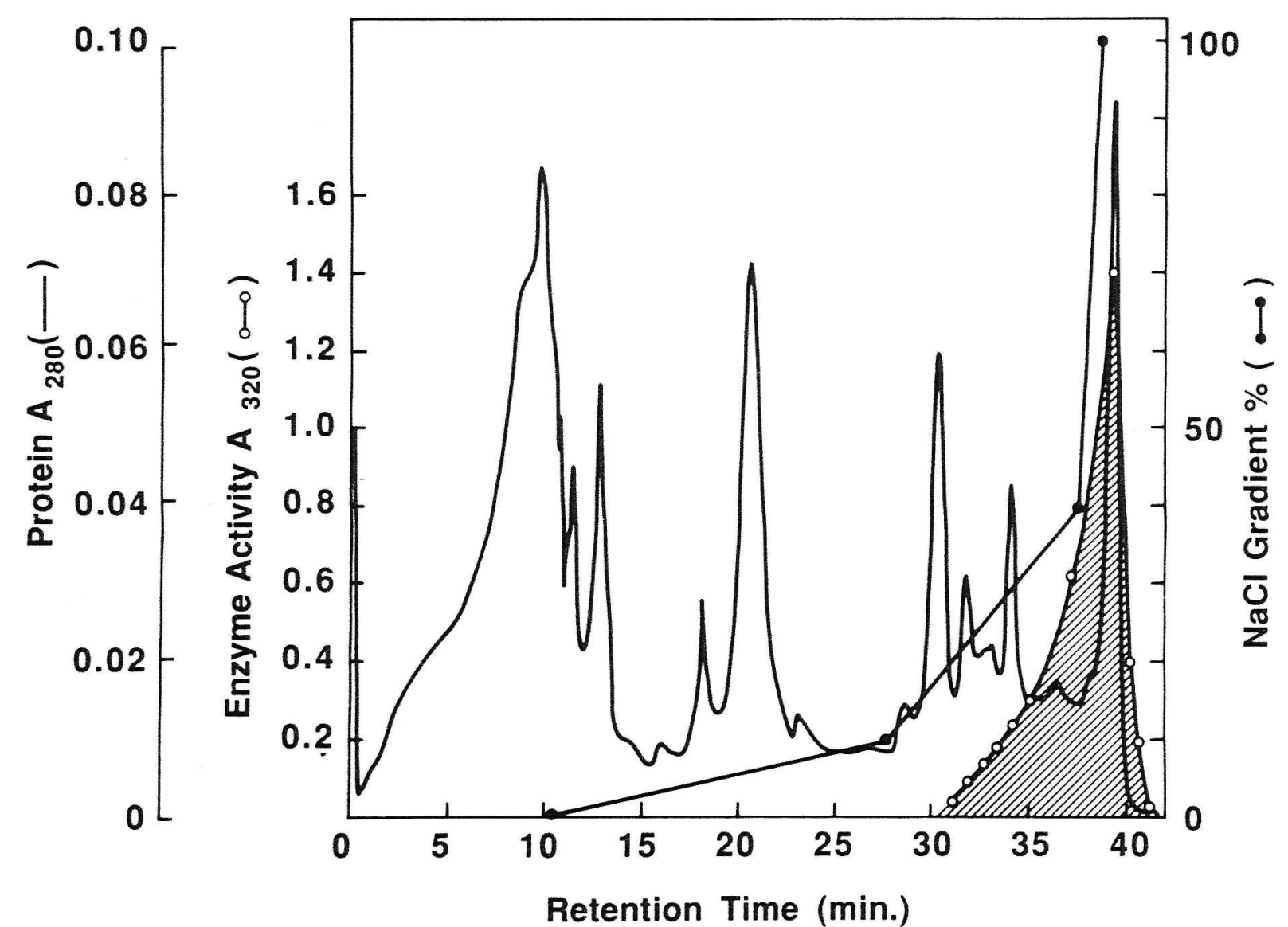

Fig. 3. FPLC on a Mono Q anion exchange column of the collagenolytic enzyme I obtained from Sephadex G-200 chromatography. A thoroughly dialyzed enzyme was injected into the column and eluted at a flow rate of $2.0 \mathrm{ml} / \mathrm{min}$ with $50 \mathrm{mM}$ Tris- $\mathrm{HCl}, \mathrm{pH} 7.8$ (containing $1.0 \mathrm{mM} \mathrm{CaCl} 2$; = buffer A) using, in buffer $\mathrm{B}$, the three-phase $\mathrm{NaCl}$ gradient indicated; the proportion of $\mathrm{NaCl}$ in buffer $\mathrm{B}$ is shown in \%. The shaded area shows the elution of the enzyme (tested with PZ-PLGPA). The portion eluted at 38-41 min was dialyzed for removal of $\mathrm{NaCl}$, concentrated and subjected to characterization studies. was detected between $\mathrm{pH} 6.5$ and 7.5 in the buffer systems shown. The following experiments were performed in $50 \mathrm{mM}$ Tris- $\mathrm{HCl}, \mathrm{pH} 7.0$, using an approximate enzyme concentration of $10^{-8} \mathrm{M}$. The enzyme was inhibited by $0.0167 \mathrm{mM}$ EDTA by $70 \%$ and by 8 -hydroxyquino-
$\mathrm{mM}$ dithiothreitol inhibited by $65 \%$. Thus, this enzyme was strongly inhibited by a typical inhibitor of sulphydryl enzymes, although it was not activated by a thiol. Very long-term $(17 \mathrm{~h})$ incubation used to test the presence of other enzyme activities with Azocasein, Azocoll, BAPNA, BANA, and the 2NAs of L-arginine, L-histidine, L-lysine, Lleucine, L-alanine and $\gamma$-L-glutamic acid as substrates, showed nil or insignificantly low rates of hydrolysis under conditions where PZ-PLGPA was hydrolyzed at a high rate.

The kinetics of the hydrolysis of PZPLGPA was studied at different substrate concentrations in $50 \mathrm{mM}$ Tris$\mathrm{HCl}(\mathrm{pH}$ 7.8). The kinetics was characterized by substrate inhibition at [PZPLGPA] $>0.46 \mathrm{mM}$ (Fig. 5). Thus, typical Michaelis-Menten behavior was not observed. Furthermore, the rate versus [PZ-PLGPA] curves were not parabolic at low substrate concentrations. A value of $0.15 \mathrm{mM}$ was estimated for $K_{m}$ (or rather $K_{s}$; vide infra), although this value should be checked after establishing the more exact nature of this kinetic behavior which may appear to be complex. This enzyme hydrolyzed gelatin (22), at a low but clearly measurable rate.

\section{Characterization of collagenolytic enzyme} II

The effect of different chemical reagents on the enzyme activity is shown in Table 4. According to these studies, the enzyme was quite sensitive to PCMB, was slightly activated by a low concentration of dithiothreitol and moderately inhibited by metal chelators. The effect of $\mathrm{pH}$ on the rate of hydrolysis of PZPLGPA catalyzed by the collagenolytic enzyme II is shown in Fig. 4B. The highest rate of hydrolysis was observed between $\mathrm{pH} 7$ and 8 . The general $\mathrm{pH}$ profile of the hydrolysis of PZ-PLGPA by both collagenolytic enzymes was relatively similar. The effect of [PZPLGPA] on the rate of the hydrolysis differed from that observed with enzyme I; the kinetics more closely followed Michaelis-Menten behavior, although substrate inhibition was observed. A $K_{m}$ value of about $0.65 \mathrm{mM}$ was obtained using the three plotting methods indicated (Fig. 6). This enzyme hydrolyzed arg-2NA as a result of partial overlapping of arginine aminopeptidases with this enzyme (Fig. 2). However, because this preparation was de- line-5-sulfonic acid and 1,10-phenantroline by $60 \%$ and $80 \%$, respectively. These compounds are typical metal chelators. $1.67 \mu \mathrm{M}$ and $0.167 \mu \mathrm{M} p$ chloromercuribenzoate (PCMB) inhibited the hydrolysis of PZ-PLGPA by $80 \%$ and $54 \%$, respectively, while 0.167 
Table 3. Partial purification of the PZ-PLGPA-hydrolyzing collagenolytic enzymes I and II from the cell sonicate of $T$. vinentii (strain ATCC 35580)

\begin{tabular}{lccccc} 
Step & $\begin{array}{c}\text { Volume } \\
(\mathrm{ml})\end{array}$ & $\begin{array}{c}\text { Protein } \\
(\mathrm{mg} / \mathrm{ml})\end{array}$ & $\begin{array}{c}\text { Total } \\
\text { protein } \\
(\mathrm{mg})\end{array}$ & $\begin{array}{c}\text { Specific } \\
\text { activity } \\
\left(\mathrm{nmol} \cdot \mathrm{min}^{-1}\right. \\
\left.\cdot \mathrm{mg}^{-1}\right)\end{array}$ & $\begin{array}{c}\text { Purifi- } \\
\text { cation }\end{array}$ \\
\hline $\begin{array}{l}\text { Cell extract } \\
\text { (after centrifugation) }\end{array}$ & 500 & 7.8 & 3,900 & 1.38 & - \\
$\begin{array}{l}\text { After Sephadex G-200 } \\
\text { (before concentration) }\end{array}$ & & & & & \\
$\quad$ Enzyme I & 500 & 0.110 & 55 & 3.10 & 2.2 \\
$\quad$ Enzyme II & 220 & 0.042 & 9 & 29.9 & 22 \\
Enzyme I after FPLC (Mono Q) & 6 & 0.012 & 0.07 & 33.8 & 24 \\
Enzyme I after dialysis & 6 & 0.010 & 0.06 & 48.3 & 35 \\
\hline
\end{tabular}

* In gel filtration on Sephadex G-200, two major peaks with activity toward PZ-PLGPA appeared. Enzyme I was further purified as indicated, whereas the lability of enzyme II necessitated its characterization after Sephadex G-200 chromatography.

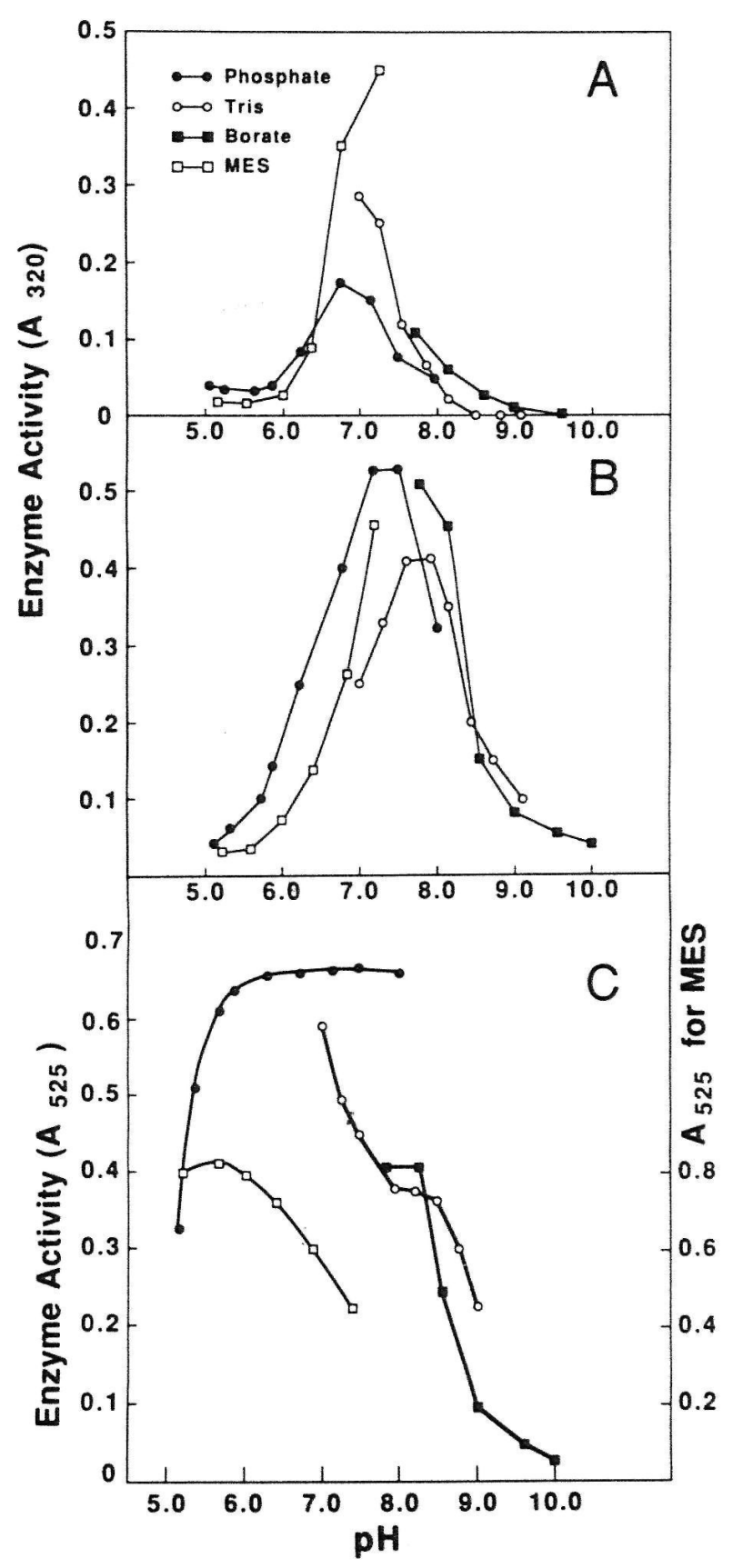

Fig. 4. Dependence on $\mathrm{pH}$ of the rate of the hydrolysis of PZ-PLGPA catalyzed by collagenolytic enzymes I (A) and II (B), and that of the hydrolysis of arg-2NA catalyzed by the high-molecular weight arginine aminopeptidase (C), of $T$. vincentii ATCC 35580. The reactions were carried out at $30^{\circ} \mathrm{C}$ in 0.1 $\mathrm{M}$ phosphate, $50 \mathrm{mM}$ Tris- $\mathrm{HCl}, 50 \mathrm{mM}$ Mes and $50 \mathrm{mM}$ borate buffers. The reactions in $\mathrm{C}$ were performed in the presence of 0.167 $\mathrm{mM}$ 1,10-phenantroline. void of other endopeptidase activity (it hydrolyzed PZ-PLGPA as the endopeptidase substrate; the other substrates shown in Table 1 were not hydrolyzed), the above characterization experiments were considered justified.

\section{Characterization of the high-molecular weight arginine aminopeptidase}

The low-molecular weight arginine am35580 lost a considerable part of their activity upon standing, dialysis and various chromatographic procedures. The enzyme eluted in the void volume of the Sephadex G-200 column (Fig. 2) was more stable under these conditions. For this study, this enzyme was obtained from a separation yielding about a sixfold activity compared to the argininge aminopeptidase peak shown in Fig. 2. This enzyme had a molecular weight

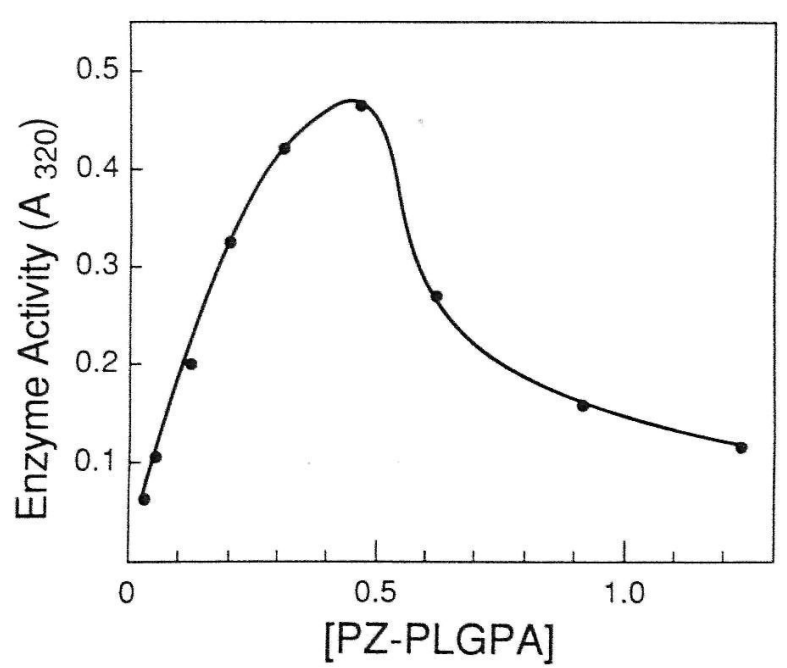

Fig. 5. The Michaelis-Menten plot of the initial velocity (in $\mathrm{A}_{320}$ ) of the hydrolysis of $\mathrm{PZ}$ PLGPA catalyzed by collagenolytic enzyme I from $T$. vincentii ATCC 35580 , showing substrate inhibition and other deviation from "normal" kinetics. The reactions were performed in $0.1 \mathrm{M}$ Tris- $\mathrm{HCl}, \mathrm{pH} 7.8$ (containing $0.1 \mathrm{mM} \mathrm{CaCl}_{2}$ ); at $30^{\circ} \mathrm{C}$. inopeptidases of $T$. vincentii ATCC of $>200,000$ (assuming approximate globular shape and unhindered filtration of the enzyme). The enzyme was inhibited by $80 \%$ and $10 \%$ in the presence of $1.67 \times 10^{-6} \mathrm{M}$ and $0.167 \times 10^{-6}$ M PCMB, respectively.

The effect of $\mathrm{pH}$ on the rate of the hydrolysis of arg-2NA in different buffer systems is shown in Fig. 4C (tested in the presence of $0.167 \mathrm{mM} \mathrm{1,10-phen-}$ antroline which stabilized the enzyme). The $\mathrm{pH}$ optimum greatly depended on the buffer used; except for Mes buffer, hibher rates of hydrolysis were measured between $\mathrm{pH} 7$ and 8 . The relative rate of hydrolysis of various amino acid 2NAs by this enzyme is shown in Table 2 . The void volume peak contained also other proteolytic enzymes, the present arginine aminopeptidase and $\gamma$-glutamyl peptidase activities being, however, dominant (judged on the basis of experiments using the substrates shown in Tables 1,2). The activities shown in Table 2 may not necessarily reflect the true situation with regard to all amino acid 2NAs studied, but these data suitably characterize the overall aminopeptidase (and BANA-hydrolyzing) activity of the void volumme fraction.

The effect of [arg-2NA] on the rate of the hydrolysis was studied as above using 3 different methods of plotting (Fig. 7). These methods yielded a mean value of $0.055 \mathrm{mM}$ for $K_{m}$, tested in 50 $\mathrm{mM}$ Tris- $\mathrm{HCl}, \mathrm{pH}$ 7.5. No significant deviation from Michaelis-Menten kin-

Table 4. Effect of various chemical reagents on the rate of the hydrolysis of PZ-PLGPA by collagenolytic enzyme II from $T$. vincentii ATCC $35580^{*}$

\begin{tabular}{lcc}
\hline Affector $(M)$ & & $\begin{array}{c}\text { Percentage of } \\
\text { inhibition }\end{array}$ \\
\hline EDTA & $1.67 \times 10^{-5}$ & 33 \\
& $1.67 \times 10^{-6}$ & 23 \\
HQSA** & $1.67 \times 10^{-4}$ & 77 \\
& $1.67 \times 10^{-5}$ & 13 \\
$1,10-$ PHE $^{* *}$ & $1.67 \times 10^{-5}$ & 51 \\
& $1.67 \times 10^{-6}$ & 0 \\
Dithiothreitol & $1.67 \times 10^{-4}$ & 16 \\
& $1.67 \times 10^{-5}$ & $(+30)^{* * *}$ \\
PCMB & $1.67 \times 10^{-6}$ & 90 \\
& $1.67 \times 10^{-7}$ & 61 \\
& $1.67 \times 10^{-8}$ & 17
\end{tabular}

* The reactions were performed in $50 \mathrm{mM}$ Tris- $\mathrm{HCl}, \mathrm{pH} 7.8$ at $30^{\circ} \mathrm{C}$ using a substrate concentration of $0.5 \mathrm{mM}$ and an enzyme concentration of about $10^{-8} \mathrm{M}$. The values shown are means of 3 of 4 determinations. ** HQSA $=8$-hydroxyquinoline sulfonic acid; 1,10-PHE =1,10-phenantroline. *** Activation. 


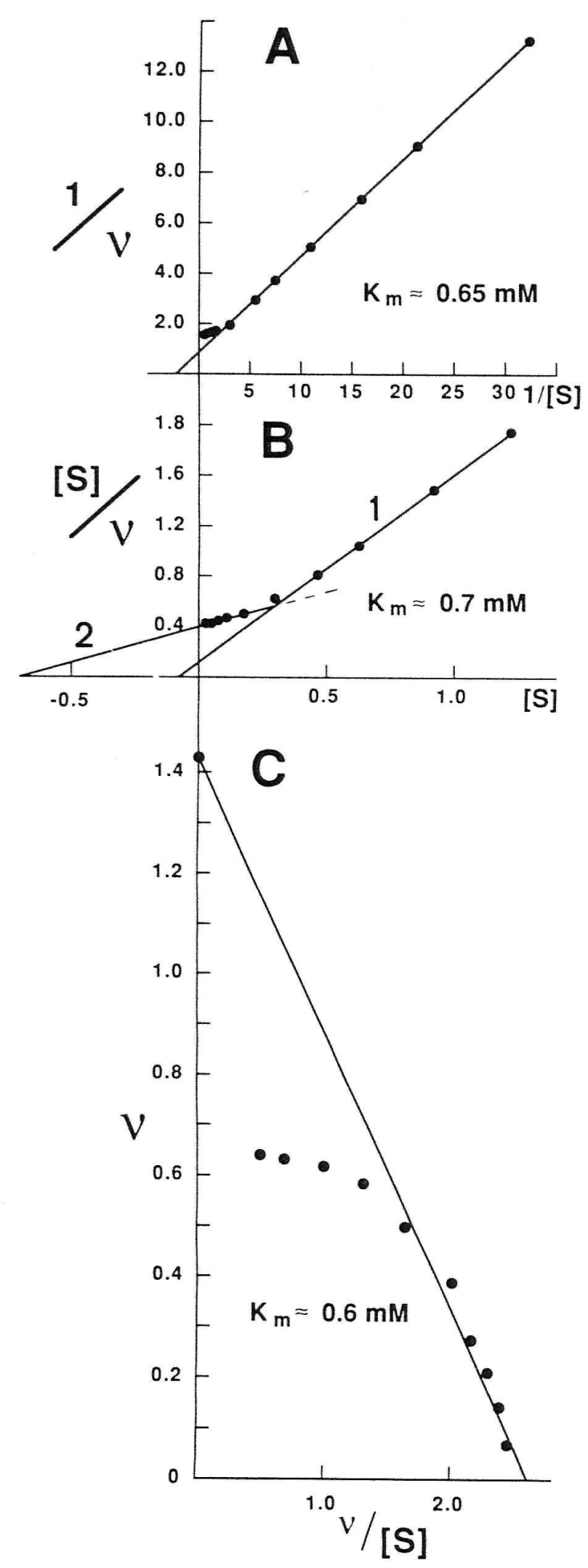

Fig. 6. Lineweaver-Burk's (A), Hanes' (B) and Woolf-Hofstee's (C) plots for the hydrolysis of PZ-PLGPA catalyzed by collagenolytic enzyme II of T. vincentii ATCC 35580. The reactions were carried out in $0.1 \mathrm{M}$ Tris$\mathrm{HCl}, \mathrm{pH} 7.5$ (containing $0.1 \mathrm{mM} \mathrm{CaCl}_{2}$ ), at $30^{\circ} \mathrm{C}$. As a result of substrate inhibition, the 4 highest substrate concentrations were disregarded in the determination of $K_{m}$ (see text). Thus, in the plot of [S]/v versus [S], Curve 1 gave an erroneous value and Curve 2 a more correct estimation of $K_{m}$ (see Discussion).

etics was observed. The presence of 1,10 -phenantroline greatly affected the course of the reaction (Fig. 8). The presence of the chelator induced substrate inhibition and slightly increased the affinity between enzyme and arg-2NA at low substrate concentrations. Therefore, this chelator was used in some characterization studies (Fig. 4C), although its presence seemed to compli-

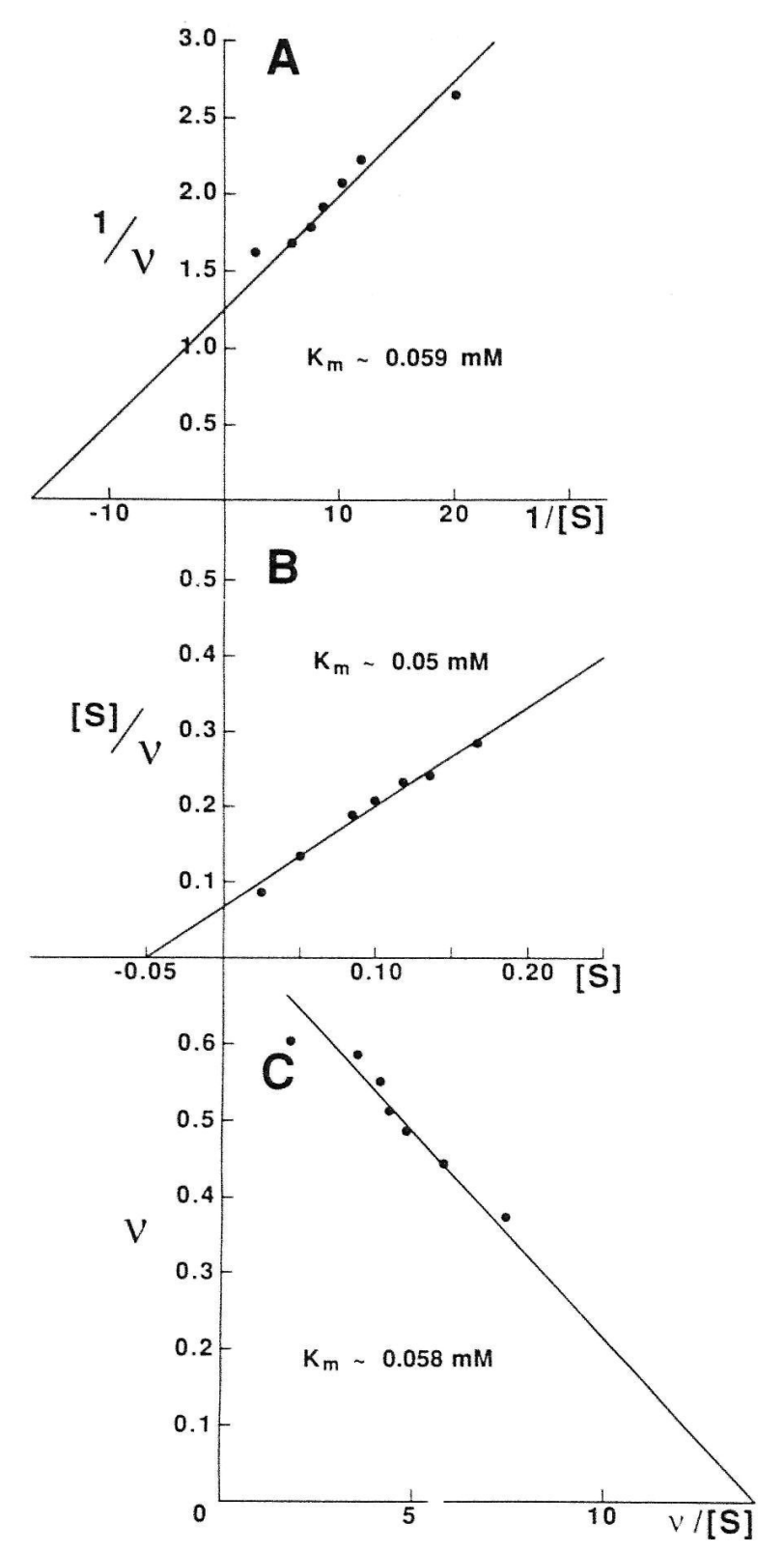

Fig. 7. Lineweaver-Burk's (A), Hanes' (B) and Woolf-Hofstee's (C) plots for the hydrolysis of arg-2NA catalyzed by the highmolecular weight arginine aminopeptidase of T. vincentii ATCC 35580 . The values shown are those of $K_{m}$. The reactions were carried out in $50 \mathrm{mM}$ Tris- $\mathrm{HCl}, \mathrm{pH} 7.0$.

cate the kinetics of the hydrolysis of arg2NA.

\section{Discussion}

The current information renders it possible to speculate about the role of the proteolytic activity exhibited by cultivable oral treponemes in the gingival crevice. $T$. denticola was characterized by high proline iminopeptidase, BANA and BAPNA activity $(21,28)$, whereas an unspeciated treponeme (strain US) displayed considerable activity toward PZ-PLGPA (38). Treponemo socranskii, a saccharolytic organism, was active toward hydroxyprolyl-2NA (38). T. vincentii studied in this investigation, contained high activity toward PZ-PLGPA, arg-NA and $\gamma$-glu-2NA. These specific characteristics suggest that although the human oral treponemes seem to specialize in the hydrolysis of specific substrates, the overall proteolytic specificity of the treponemes is relatively broad. It is interesting from the clinical point of view that the hydrolysis of PZPLGPA has been a common denominator in all oral treponemes studied by us $(20,38)$. The PZ-PLGPA-hydrolyzing enzymes also showed more constant and consistent activity levels than many other peptidases whose activities often differed more significantly between species and strains (20). The PZPLGPA-hydrolyzing enzymes may thus be regarded as constitutive proteinases of these treponemes.

This study does not claim that the two major PZ-PLGPA-hydrolyzing enzymes of $T$. vincentii represented "true" collagenases. True microbial collagenases have been more thoroughly studied only in Clostridium histolyticum (2-5, 12), Achromobacter (42), and Bacillus cereus (22). Further studies on radioactively labelled collagen and more detailed comparative enzymology are needed to elucidate this question. However, PZ-PLGPA has been recommended and intensively used as a chromogenic substrate for bacterial collagenases $(3,22,46)$. Bond and van Wart, for example, stated that the best way to compare the activities of bacterial collagenases is to employ PZPLGPA as substrate (3). The present collagenolytic enzymes I and II showed high activity toward PZ-PLGPA and did not significantly hydrolyze other peptidase substrates tested. Furthermore, enzyme I hydrolyzed gelatin, a modified collagen. However, these enzymes may not be active on insoluble collagen, as evidenced by the inability

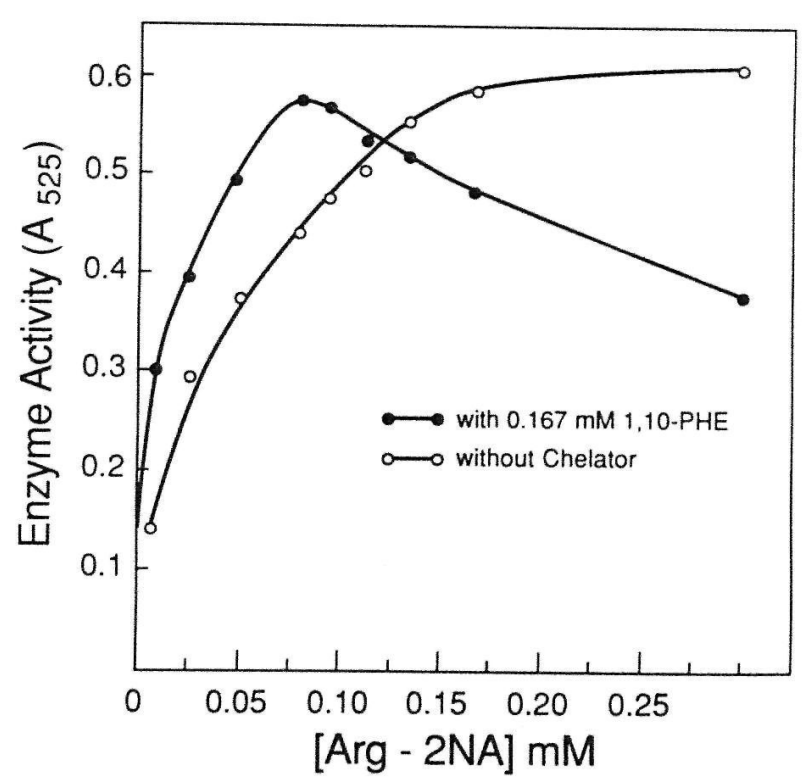

Fig. 8. The Michaelis-Menten plot of the initial velocity (in $\mathrm{A}_{525}$ ) of the hydrolysis of arg2NA catalyzed by the high-molecular weight arginine aminopeptidase in the presence of $0.167 \mathrm{mM} \mathrm{1,10-phenantroline}$ and without added chelator. The reactions were carried out at $30^{\circ} \mathrm{C}$ in $0.1 \mathrm{M}$ Tris- $\mathrm{HCl}$ buffer, $\mathrm{pH}$ 7.5. 
of the crude enzyme preparation and the partially purified enzymes to hydrolyze Azocoll. The in vivo substrate(s) of these enzymes should then be liberated by other mechanisms, for example, by tissue collagenases.

The Michaelis law was obeyed at lower substrate concentrations with collagenolytic enzyme II, while the kinetics of enzyme I deviated from this law at most substrate levels tested. The velocity fell off at high concentrations with both enzymes. This effect may have resulted from a number of different causes. In a "simple" peptidolytic reaction, such as the cleavage of the LeuGly bond by a monoreactant enzyme, it is likely that the enzyme, with its most likely extended binding domain, may contain 2 or more groups, each combining with a particular part of the molecule. At high [PZ-PLGPA] this may result in the formation of ineffective complexes. This situation corresponded to competitive inhibition by the substrate itself and thus the value obtained from the intercept of the line in the double reciprocal plot, for example (Fig. 6A), does not give $K_{m}$, but $K_{s}$, which is the dissociation constant of an inactive $\mathrm{ES}_{2}$ complex. Endopeptidases that hydrolyze peptide bonds often contain an extended active site (25) which would render this type of kinetic behavior possible. Because this type of kinetic examinations require more detailed studies, we are here restricting ourselves to the use of $K_{m}$ rather than $K_{s^{\prime}}$ (Fig. 6).

The plots of $v$ versus $v /[S]$ can be used to prove if one or more enzymes active on the same substrate are present (32). If more than one enzyme is involved, this plot tends to display pronounced curvature which is quite different from that associated with substrate inhibition (in the former case the experimental points arranged on a concave curve). In none of the cases studied was such kinetic behavior noted. This suggests that the collagenolytic enzymes I and II were essentially free from other enzymes hydrolyzing PZ-PLGPA entitling us to draw conclusions about the data obtained. Nor was such behavior observed in the hydrolysis of arg-2NA.

Although inflammatory processes in the periodontal pocket are frequently characterized by the presence of highly active host tissue enzyme participating in numerous biochemical events, bacterial enzymes are also present and most likely contribute significantly to the entire process. It was stated more than twenty years ago that the close proximity of oral tissues to microbial enzymes almost certainly results in the hydrolysis of the former (17). This direct role of "periodontophatic" hydrolases has received abundant attention recently. A larger number of studies have described the presence of different peptidases in periodontopathic organisms $(11,14,15$, 20-23, 26-29, 31, 35-37, 40, 41, 43) or in subgingival plaque $(1,7)$, and (bacterial) collagenase activity was demonstrated in the gingival sulcal debris, cervicular fluid, or periodontopathic organisms (1, $22,23,29,34,41)$. It is of special interest that a bacterial collagenase was shown to be a chemoattractant for human neutrophils (44). Among these enzymes collagenolytic proteinases elicit special interest, as the evolution of these enzymes, like the spirochete endopeptidases, must have taken place in close association with the evolution of the connective tissue itself. Such periodontopathogens as the treponemes, thus represent an old peptidolytic trait. This view may be further extrapolated to comprise other organisms isolated from subgingival plaque: studies which will be published later suggest that PZ-PLGPA-hydrolyzing enzymes are present not only in treponemes, but also in fusobacteria, and in Capnocytophaga, Bacillus and Streptococcus species, all of which display pathogenicity in the periodontium or elsewhere in host tissues. Furthermore, all PZ-PLGPAhydrolyzing enzymes discovered in periodontopathic organisms also hydrolyze various soluble and/or insoluble collagenous substances.

\section{Acknowledgements}

Supported by DRI Grant \#DE02475 and by a grant from the Nutritional Research Foundation of the Finnish Sugar Company, Helsinki, Finland.

\section{References}

1. Alfano MC, Morhart RE, Metcalf G, Drummond JF. Presence of collagenase from Clostridium histolyticum in gingival sulcal debris of a primitive population. J Dent Res 1974: 53: 142.

2. Bond MD, Steinbrink DR, Van Wart HE. Identification of essential amino acid residues in Clostridium histolyticum collagenase using chemical modification reactions. Biochem Biophys Res Commun 1981: 102: 243-249.

3. Bond MD, Van Wart HE. Purification and separation of individual collagenases of Clostridium histolyticum using red dye ligand chromatography. Biochemistry 1984: 23: 3077-3085.

4. Bond MD, Van Wart HE. Characterization of the individual collagenases from Clostridium histolyticum. Biochemistry 1984: 23: 3085-3091.

5. Bond MD, Van Wart HE. Relationship between the individual collagenases of Clostridium histolyticum: evidence for evolution by gene duplication. Biochemistry 1984: 23: 3092-3099.

6. Bradford MM. A rapid and sensitive method for the quantitation of microgram quantities of protein utilizing the principle of protein-dye binding. Anal Biochem 1976: 72: 248-254

7. Bretz WA, Loesche WJ. Characteristics of trypsin-like activity in subgingival plaque samples. J Dent Res 1987: 66: 1668-1672.

8. Canale-Parola E. Physiology and evolution of spirochetes. Bacteriol Rev 1977: 41: 181-204.

9. Chavira R, Jr, Burnett TJ, Hageman JH. Assaying proteinase with azocoll. Anal Biochem 1984: 136: 446-450.

10. Erlanger BF, Kokowsky N, Cohen W. The preparation and properties of two new chromogenic substrates of trypsin. Arch Biochem Biophys 1961: 146: 343-348.

11. Fiehn N-E. Enzyme activities from eight small-sized oral spirochetes. Scand J Dent Res 1986: 94: 132-140.

12. Galardy RE, Grobelny D. Inhibition of collagenase from Clostridium histolyticum by phosphoric and phosphonic amides. Biochemistry 1983: 22: 4556-4561.

13. Harwood CS, Canale-Parola E. Ecology of spirochetes. Ann Rev Microbiol 1984: 38: $161-192$.

14. Laughon BE, Syed SA, Loesche WJ. API ZYM system for identification of Bacteroides spp., Capnocytophagaa spp., and spirochetes of oral origin. J Clin Microbiol 1982: 15: 97-102.

15. Loesche WJ, Laughon BE. Role of spirochetes in periodontal disease. In: Genco RJ, Mergenhagen SE, eds. Host-parasite interactions in periodontal diseases. Washington DC: Am Soc Microbiol 1982: $62-75$.

16. Loesche WJ, Syed SA, Stoll J. Trypsinlike activity in subgingival plaque. A diagnostic marker for spirochetes and periodontal disease? J Periodontol 1987: 58: 266-273.

17. Mäkinen KK, Paunio KU. Studies on oral enzymes. VI. Hydrolysis of periodontal collagen by plaque enzyme extract. Acta Odont Scand 1966: 24: 731-745.

18. Mäkinen KK, Mäkinen P-L. Effect of sodium chloride on substrate constant and maximum velocity in the enzymic hydrolysis of N-L-aminoacyl-2-naphthylamines and N-L-aminoacyl-p-nitroanilines. Acta Chem Scand 1971: 25: 969-975. 
19. Mäkinen KK, Mäkinen P-L. Purification and characterization of two human erythrocyte arylamidases preferentially hydrolysing $\mathrm{N}$-terminal arginine or lysine residues. Biochem J 1978: 175: 1051-1067.

20. Mäkinen KK, Syed SA, Mäkinen P-L, Loesche WJ. Benzoylarginine peptidase and iminopeptidase profiles of Treponema denticola strains isolated from the human periodontal pocket. Curr Microbiol 1986: 14: 85-89.

21. Mäkinen KK, Syed SA, Mäkinen P-L, Loesche WJ. Dominance of iminopeptidase activity in the human oral bacterium Treponema denticola ATCC 35405. Curr Microbiol 1987: 14: 341-346.

22. Mäkinen KK, Mäkinen P-L. Purification and properties of an extracellular collagenolytic protease produced by the human oral bacterium Bacillus cereus (strain Soc 67). J Biol Chem 1987: 262: 12488-12495.

23. Mayrand D, Grenier D. Detection of collagenase activity in oral bacteria. Can J Miçrobiol 1985: 31: 134-138.

24. Moore GL. Use of azo-dye-bound collagen to measure reaction velocities of proteolytic enzymes. Anal Biochem 1969: 32: $122-127$.

25. Morihara K, Tsuzuki H. Thermolysin: kinetic study with oligopeptides. Eur J Biochem 1970: 15: 374-380.

26. Nakamura M, Slots J. Aminopeptidase activity of Capnocytophaga. J Periodont Res 1982: 17: 597-603.

27. Nitzan D, Sperry JF, Wilkins TD. Fibrinolytic activity of oral anaerobic bacteria. Arch Oral Biol 1978: 23: 465-470.

28. Ohta K, Mäkinen KK, Loesche WJ. Purification and characterization of an enzyme produced by Treponema dentic- ola capable of hydrolyzing synthetic trypsin substrates. Infect Immun 1986: 53: $213-220$.

29. Robertson PB, Lantz M, Marucha PT, Kornman KS, Trummel CL, Holt SC. Collagenolytic activity associated with Bacteroides species and Actinombacillus actinomycetemcomitans. J Periodont Res 1982: 17: 275-283.

30. Sachar L, Winter KK, Sicher N, Frankel S. Photometric method for estimation of elastase activity. Proc Soc Exp Biol Med 1955: 90: 323-326.

31. Sandholm L. Proteases and their inhibitors in chronic inflammatory periodontal disease. J Clin Periodont 1986: 13: 19-26.

32. Segel IH. Enzyme kinetics. New York: Wiley, 1975: 64-71.

33. Seppä HE, Järvinen M. Rat skin main neutral protease: purification and properties. J Invest Dermatol 1978: 70: 84-89.

34. Smith LB, Rule JT, Rosen S. Evaluation of collagenase activity in the crevicular fluid of children. J Dent Res 1974: 53 : 150.

35. Sorsa T, Uitto V-J, Suomalainen K, Turto $\mathrm{H}$, Lindy $\mathrm{S}$. A trypsin-like protease from Bacteroides gingivalis: partial purification and characterization. J Periodont Res 1987: 22: 375-380.

36. Suido H, Nakamura M, Mashimo PA, Zambon JJ, Genco RJ. Arylaminopeptidase activities of oral bacteria. J Dent Res 1986: 65: 1335-1340.

37. Suido H, Neiders ME, Barua PK, Nakamura M, Mashimo PA, Genco RJ. Characterization of N-CBz-glycyl-glycyl-arginyl peptidase and glycyl-prolyl peptidase of Bacteroides gingivalis. J Periodont Res 1987: 22: 412-418.

38. Syed SA, Salvador SL, Mäkinen KK, Mäkinen P-L, Loesche WJ. Biochemical comparison of peptidases in oral Tre- ponema sp. Abstr K137, Ann Meet Am Soc Microbiol 1987.

39. Syed SA, Salvador SL, Loesche WJ. Enzyme profiles of oral spirochetes in RapID ANA system. J Clin Microbiol 1988 (in press).

40. Takahashi T, Asari K, Sato N, Yamaya S-I, Sugahara T. Purification and properties of an aminopeptidase from Treponema phagedenis (Reiter strain). Curr Microbiol 1985: 12: 283-288.

41. Toda K, Otsuka M, Ishikawa Y, Sato M, Yamamoto Y, Nakamura R. Thioldependent collagenolytic activity in culture media of Bacteroides gingivalis. J Periodont Res 1984: 19: 372-381.

42. Tong NT, Tsugita A, Keil-Dlouha V. Purification and characterization of two high-molecular-mass forms of Achromobacter collagenase. Biochem Biophys Acta 1986: 874: 296-304.

43. Uitto V-J, Chan ECS, Chin Quee T. Initial characterization of neutral proteinases from oral spirochetes. J Periodont Res 1986: 21: 95-100.

44. Walter RJ. Clostridial collagenase: a chemoattractant for human neutrophils. Inflamation 1986: 10: 347-361.

45. Whitaker JR, Granum PE. An absolute method for protein determination based on differences in absorbance at 235 and $280 \mathrm{~nm}$. Anal Biochem 1980: 109: 156-159.

46. Wünsch E, Heidrich HG. Quantitative Bestimmung der Kollagenase. Z Physiol Chem 1963: 333: 149-151.

47. Yoshimura F, Nishikata M, Suzuki T, Hoover CI, Newbrun E. Characterization of a trypsin-like protease from the bacterium Bacteroides gingivalis isolated from human dental plaque. Arch Oral Biol 1984: 29: 559-564. 
This document is a scanned copy of a printed document. No warranty is given about the accuracy of the copy. Users should refer to the original published version of the material. 